\title{
A Case of Deep Vein Thrombosis in the Postpartum Period
}

\author{
Hande Atalay', Fatih Teker², Banu Boyuk', Aslan Çelebi', Yavuz Ayar ${ }^{3}$ İsmail Ekizoğlu \\ ${ }^{1}$ Clinic of Internal Medicine, Gaziosmanpaşa Taksim Training and Research Hospital, İstanbul, Turkey \\ 2Department of Medical Oncology, Samsun 19 Mayıs University Faculty of Medicine, Samsun, Turkey \\ ${ }^{3}$ Department of Internal Medicine, Uludağ University Faculty of Medicine, Bursa, Turkey
}

\section{ABSTRACT}

The main reason for the increased risk of thromboembolism in pregnancy is hypercoagulability, which has likely evolved to protect women from the bleeding challenges of miscarriage and childbirth. Women are at a 4- to 5-fold increased risk of thromboembolism during pregnancy and the postpartum period compared with when they are not pregnant. Risk factors include a history of thrombosis, inherited and acquired thrombophilia, maternal age greater than 35, certain medical conditions, and various complications of pregnancy and childbirth. In this report, a case of a 25-year-old woman diagnosed with deep vein thrombosis in the fourth week of the postpartum period is presented. After the investigating the reasons of deep vein thrombosis, heterozygote factor $V$ Leiden mutation and heterozygote activated protein c resistance were detected. This case is presented in order to emphasize that hereditary risk factors must be investigated, especially in young patients, although the patient already had an acquired risk factor such as pregnancy. (JAREM 2015; 5: 28-30)

Keywords: Deep vein thrombosis, pregnancy, factor $\vee$ Leiden mutation, activated protein $C$ resistance

\section{INTRODUCTION}

Pregnancy is a physiological process that is related with a high incidence of thromboembolic events. The incidence of pregnancy-related venous thromboembolic events was 13 per 10,000 deliveries (1); therefore, it is an important cause of morbidity and mortality in developed countries. The risk of venous thrombosis increases by 5 to 6 times during pregnancy (2). Pregnancy itself induces a prothrombotic state, with an increase in coagulation factors, a decrease in natural anticoagulants such as the coagulation inhibitor protein $\mathrm{S}$, and impairment of fibrinolysis, which is probably mediated by an increase in plasminogen activator inhibitor. These procoagulant changes are important for minimizing blood loss during delivery. Pregnancy is also marked by the presence of two other components of Virchow's triad: venous stasis and endothelial injury. These homeostatic changes cause an increased risk for venous thromboembolism (VTE) (3). In the context of inherited genetic risk factors in DVT, factor $V$ Leiden and factor II mutations are reported as the most frequent causes (4-6). History of thrombosis in young, such as recurrent venous thrombosis, family history of thrombosis, arterial thrombosis, heparin resistance, warfarin-induced skin necrosis, neonatal purpurafulminans, history of estrogen medication and thrombosis during pregnancy, entail investigations for genetically inherited risk factors (7). For this purpose, among such patients, factor $\mathrm{V}$ Leiden and prothrombin G20210A mutations, protein C-S, antithrombin 3, and homocysteine levels have been frequently studied recently. For a definite diagnosis, one should be cautious about the timing of the tests and the interfering factors. Here we report a case of woman presenting with deep vein thrombosis in the postpartum period who turned out to be positive for heterozygote factor $\mathrm{V}$ Leiden mutation and heterozygote protein $\mathrm{C}$ resistance. This case highlights the importance of investigating hereditary risk factors in patients with an acquired risk factor for venous thrombosis.

\section{CASE PRESENTATION}

A 25-year-old woman presented to our hospital in the postpartum fourth week with complaints of swelling on her left leg and high fever. She reported that she had massive hemorrhage during delivery and had thus taken multiple blood transfusions and was advised bed rest. Her medical history did not reveal any abortion or other disease. This was her first pregnancy, which was uneventful till delivery. Her family history was unremarkable for thrombosis or recurrent miscarriages.

On physical examination, her vital signs were within normal limits. Cardiologic examination revealed systolic murmur over mitral area. Her respiratory system and abdominal examination was normal. The peripheral and central pulses were equal and regular bilaterally; however, her left lower extremity beginning from the inguinal area was hyperemic, increased in diameter, and edematous. Doppler USG of the left lower limb showed large thrombus in the left common femoral vein as well as in vena saphena magna, extending into the proximal part of the superficial femoral vein. The routine laboratory tests are shown in Table 1. Iron deficiency anemia was detected, and her hemoglobin level was increased to 10.6 by blood transfusion. In this case, although the patient had already had an acquired risk factor such as pregnancy, she was screened for inherited thrombophilia such as factor $\mathrm{V}$ Leiden, prothrombin gene mutation, protein $C$ resistance, and antithrombin 3 levels. She was het- 
Table 1. Routine biochemical parameters of the patient

\begin{tabular}{|c|c|c|}
\hline Variable & Patient value & Normal value \\
\hline $\mathrm{Hg}(\mathrm{g} / \mathrm{dL})$ & 5.8 & $12-18$ \\
\hline Hct (\%) & $40.4 \%$ & $39.5-50.3$ \\
\hline WBC $(K / \mu L)$ & 8500 & $4100-10.900$ \\
\hline Platelets $(\mathrm{K} / \mu \mathrm{L})$ & 622.000 & $156.000-373.000$ \\
\hline Sedimentation $(\mathrm{mm} / \mathrm{h})$ & 103 & $<25$ \\
\hline Fasting glucose level (mg/dL) & 109 & $76-100$ \\
\hline BUN (mg/dL) & 9 & $8-26$ \\
\hline SGOT (IU/mL) & 31 & $5-40$ \\
\hline SGPT (IU/mL) & 38 & $5-55$ \\
\hline INR (IU) & 1.13 & $0.8-1.2$ \\
\hline APTT (second) & 27 & $25-38$ \\
\hline PT (second) & 11.2 & $10.4-1$ \\
\hline $\begin{array}{l}\text { CRP (nephelometric method, } \\
\mathrm{mg} / \mathrm{dL} \text { ) }\end{array}$ & 7.2 & $0-0.6$ \\
\hline Folic acid (ng/mL) & 10.80 & $>5.21$ \\
\hline Vitamin B12 (pg/mL) & 131 & $134-590$ \\
\hline
\end{tabular}

Table 2. Results of the thrombophilia tests

\begin{tabular}{|l|c|c|}
\hline Variable & Result & Normal values \\
\hline Prothrombin G20210A mutation & Normal & - \\
\hline Protein S (mg/L) & 20 & $12-21$ \\
\hline Protein C (mg/L) & 3.26 & $1.67-3.16$ \\
\hline Antithrombin 3 (mg/dL) & 30.9 & - \\
\hline $\begin{array}{l}\text { Factor V Leiden mutation } \\
\text { (G1691A) }\end{array}$ & $\begin{array}{c}\text { Positive for } \\
\text { heterozygosity }\end{array}$ & - \\
\hline APC resistance (APC-P) & $\begin{array}{l}\text { 1.48 positive for } \\
\text { heterozygosity }\end{array}$ & $>3(\mathrm{~N})$ \\
\hline APC: activated protein C resistance & & \\
\hline
\end{tabular}

erozygous for factor $\mathrm{V}$ Leiden mutation and activated protein $\mathrm{C}$ resistance (Table 2). A lifelong treatment with warfarin was initiated and followed up with regular control of INR levels.

\section{DISCUSSION}

Most of the causes of thrombosis are acquired factors. A genetically inherited heterozygote gene defect alone does not increase the risk of thrombosis significantly. However, inherited factors create a risk for thrombosis in the long term and along with acquired prothrombotic stimuli (8). The point is that, thrombotic events generally from the interaction of hereditary and acquired risk factors. Among hereditary gene defects causing thrombosis, factor $V$ Leiden mutation is the most common factor (40-60\%) (9). Autosomal dominant factor $\vee$ Leiden mutation is observed in $7 \%$ of the European population, whereas in 4.5-7.1\% of the Turkish population (10, 11). However, in another study, the prevalence of factor $\mathrm{V}$ Leiden mutation in Turkey was reported as 10\% (12). Factor $V$ Leiden was detected in 11-29\% of patients with VTE. It was reported that the risk of VTE is 3 to 8 times higher in heterozygote carriers and 80 times higher in homozygote carries compared with the normal population $(13,14)$.

On the other hand, the phenotype of APC resistance was also frequently found among thrombosis patients. Koster et al. (15) reported in 1993 that this phenotype is the most important hereditary risk factor for developing DVT. The majority (>90\%) of hereditary APCR subjects have the same genetic abnormality, i.e., factor $\mathrm{V}$ Leiden with a G1691A alteration causing an Arg 506Gln substitution. In 1994, Rogier M Bertina et al. (16) reported that $>80 \%$ of patients with APC resistance were carriers of the same mutation in the gene of factor $V$, i.e., a $G \rightarrow$ A transition at position 1691, in exon 10, which predicts the replacement of Arg 506 by $\mathrm{Gln}$ in the factor $\mathrm{V}$ molecule (factor $V$ Leiden). All carriers of the factor $V$ mutation (and only these) had APC-SRs. Because a factor $V$ Leiden mutation increases the risk for venous thrombosis, peripheral vascular disease, cerebrovascular disease, pulmonary emboli, and myocardial infarction, individuals with thrombophilic risk factors should be screened for this mutation and its carriers $(6,17$, 18). Conditions indicating factor $V$ mutation analysis are as followed: venous thrombosis before the age of 50 years, venous thrombosis at any age without a precipitating factor, recurrent venous thrombosis, unusual site of presentation (cerebral, mesenteric, portal, or hepatic veins), thrombosis during pregnancy and the postpartum period, history of VTE under treatment with an oral contraceptive or hormone replacement therapy, and a family history of venous thrombosis (6). Considering that our patient was 25 years old and diagnosed with venous thrombosis at postpartum fourth week, she was screened for factor $V$ Leiden mutation and resulted with heterozygosity.

Even though antithrombin 3 (0.02-0.05\%), protein S and C (0.1$0.5 \%)$ deficiency are rarely seen, a study in our country revealed that thrombophilias due to antithrombin $3(5.4 \%)$, protein $C$ $(13.51 \%)$, and protein $\mathrm{S}(13.51 \%)$ deficiency are more common, contrary to activated protein $C$ resistance $(5.4 \%)$, which is rarely seen (19). In our case, heterozygosity of activated protein $C$ resistance was detected although it is rarely seen in our country.

\section{CONCLUSION}

Because of the combination of thrombophilic risk factors (heterozygosity of factor $V$ Leiden mutation and protein $C$ resistance), the present case was initiated on lifelong warfarin therapy and, on follow-up, she did not have any other recurrent thrombosis. This case emphasizes that despite the presence of acquired thrombophilic risk factors, patients should be screened for hereditary risk factors, especially in countries where the prevalence of hereditary thrombophilia is high. 
Informed Consent: Written informed consent was obtained from patient who participated in this study.

Peer-review: Externally peer-reviewed.

Author contributions: Concept - H.A.; Design - H.A.; Supervision - B.B.; Resource - F.T.; Materials - I.E.; Data Collection and/or Processing - F.T.; Analysis and/or Interpretation - A.Ç.; Literature Search - H.A.; Writing H.A.; Critical Reviews - B.B.

Conflict of Interest: No conflict of interest was declared by the authors.

Financial Disclosure: The authors declared that this study has received no financial support.

\section{REFERENCES}

1. Lindqvist $P$, Dahlback $B$, Marsal $K$. Thrombotic risk duringpregnancy: A population study. Obstet Gynecol 1999; 94: 595-9. [CrossRef]

2. Melis F, Vandenbrouke JP, Buller HR, Colly LP, Bloemenkamp KWM Estimates of risk of venous thrombosis during pregnancy and puerperium are not influenced by diagnostic suspicion and referral basis. Am J Obstet Gynecol 2004; 191: 825-9. [CrossRef]

3. Won HS, Kim do Y, Yang MS, Lee SJ, Shin HH, Park JB. Pregnancyinduced hypertension, but not gestational diabetes mellitus, is a risk factor for venous thromboembolism in pregnancy. Korean Circ J 2011; 41: 23-7. [CrossRef]

4. Margaglione M, Brancaccio V, De Lucia D, Martinelli I, Ciampa A, Grandone E, et al. Inherited thrombophilic risk factors and venous thromboembolism: distinct role in peripheral deep venous thrombosis and pulmonary embolism. Chest 2000; 118: 1405-11. [CrossRef]

5. Legnani C, Palareti G, Guazzaloca G, Cosmi B, Lunghi B, Bernardi $F$, et al. Venous thromboembolism in youngwomen; role of thrombophilic mutations and oral contraceptive use. Eur Heart J 2002; 23: 984-90. [CrossRef]

6. Sılan F, Zafer C. Faktör V Leiden mutasyonu. Düzce Tıp Fakültesi Dergisi 2004 ; 1 : 33-6.
7. Demirel C, Kaya C, Sonmezer M, Soylemez F, Dincer Cengiz S. Factor $\mathrm{V}$ leiden mutation in a patient recurrent pregnancy loss and deep vein thrombosis. Turkiye Klinikleri J Gynecol Obst 2003; 13: 62-5.

8. Dahlback B. Physiological anticoagulation. Resistance to activated protein $\mathrm{C}$ and venous thromboembolism. J Clin Invest 1994; 94: $923-$ 7. [CrossRef]

9. Oner F, Kaya A, Dogan R, Numanoglu N. Genetic risk factors of venous thromboembolism. Tuberk Toraks 2003; 51: 60-9.

10. Irdem A, Devecioglu C, Batun S, Soker M, Sucakli IA. Prevalence of factor $V$ Leiden and prothrombin G20210A gene mutation. Saudi Med J 2005; 26: 580-3.

11. Gurgey A, Mesci L. The prevalence of factor V Leiden (1691 G-->A) mutation in Turkey. Turk J Pediatr 1997; 39: 313-5.

12. Akar N, Akar E, Dalgın G, Sozuoz A, Onurlu K, Cin S. Frequency of factor $V(1691->$ A) mutation in Turkish population. Thromb Haemost 1997; 78: 1527-8.

13. Okumus G, Kiyan E, Arseven O, Tabak L, Diz-Kucukkaya R, Unlucerci $Y$, et al. Hereditary thrombophilic risk factors and venous thromboembolism in Istanbul, Turkey: the role in different clinical manifestations of venous thromboembolism. Clin Appl Thromb Hemost 2008;14:168-73. [CrossRef]

14. Rees DC, Cox M, Clegg JB. World distribution of factor $V$ Leiden. Lancet 1995; 346: 1133-4. [CrossRef]

15. Koster T, Rosendaal FR, de Ronde H, Briët E, Vandenbroucke JP, Bertina RM. Venous thrombosis due to poor anticoagulant response to activated protein C: Leiden Thrombophilia Study. Lancet 1993; 342: 1503-6. [CrossRef]

16. Bertina RM. Factor $V$ Leiden and other coagulation factor mutations affecting thrombotic risk. Clin Chem 1997; 43: 1678-83.

17. Baykan M, Celik S, Uçar F, Kaplan S, Ovali E, Erdöl C. Effects of factor $\checkmark$ Leiden mutations on prognosis in patients with acute myocardial infarction. Anadolu Kardiyol Derg 2001;1: 242-5.

18. Kafkas S, Kadıköylü G. Gebelik ve kalıtsal trombofili. ADÜ Tıp Fakültesi Dergisi 2005; 6: 43-50.

19. Demir M, Vural O, Sunar H, Altun A, Yorulmaz F, Ozbay G. The prevalence of hereditary thrombophilia in the Trakya region of Turkey. Yonsei Med J 2000; 41: 436-40. [CrossRef] 